\title{
Effect of Corruption on Tax Revenues in the Middle East
}

\author{
Patrick A. Imam and Davina F. Jacobs
}





\title{
IMF Working Paper
}

IMF Institute and Fiscal Affairs Department

\section{Effect of Corruption on Tax Revenues in the Middle East}

\author{
Prepared by Patrick A. Imam and Davina F. Jacobs ${ }^{1}$ \\ Authorized for distribution by Arend Kouwenaar and Thanos Catsambas
}

November 2007

\begin{abstract}
This Working Paper should not be reported as representing the views of the IMF. The views expressed in this Working Paper are those of the authors and do not necessarily represent those of the IMF or IMF policy. Working Papers describe research in progress by the authors and are published to elicit comments and to further debate.

This study estimates the impact of corruption on the revenue-generating capacity of different tax categories in the Middle East. We find that the low revenue collection as a share of GDP there compared to other middle-income regions is due in part to corruption, and certain taxes are more affected than others. Taxes that require frequent interaction between the tax authority and individuals, such as taxes on international trade, seem to be more affected by corruption than most other types of taxation. This suggests that if governments need to raise more tax revenues in a way that minimizes distortions and maximizes social welfare, they should implement reforms that either reduce corruption or raise revenues from tax categories that are less susceptible to corruption. Possible reforms of the revenue system and administration are examined.

JEL Classification Numbers: H21; H26; H83

Keywords: Corruption; governance; revenue administration, taxation Authors E-Mail Addresses: pimam@imf.org; djacobs@,imf.org

\footnotetext{
${ }^{1}$ Patrick Imam is an economist in the African Department and Davina Jacobs is senior economist in the Fiscal Affairs Department. The paper was presented at the 63rd Congress of the International Institute of Public Finance, held August 27-30 at Warwick University. We would like to thank Peter Barrand, Olivier Benon, Jean-Paul Bodin, Thanos Catsambas, Saade Chami, Edward Gardner, Anne Grant, Zubair Iqbal, Anna Ivanova, Michael Keen, Michel Lazare, Todd Schneider, and Ling Hui Tan for their valuable comments.
} 


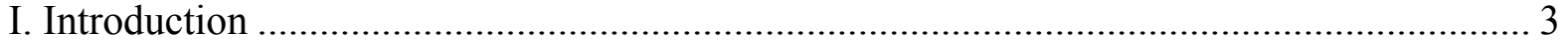

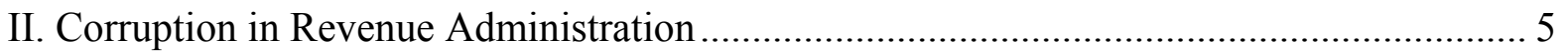

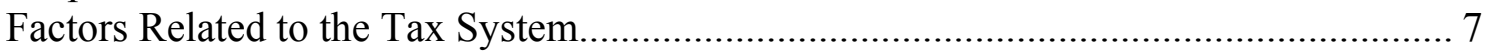

Factors Related to Tax Administration ....................................................................... 7

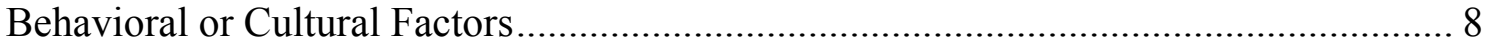

III. Comparison of Taxation Systems in Middle East Countries .............................................. 8

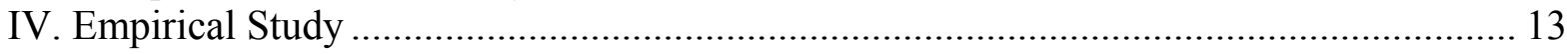

A. Hypothesis and Empirical Specifications …………................................................... 14

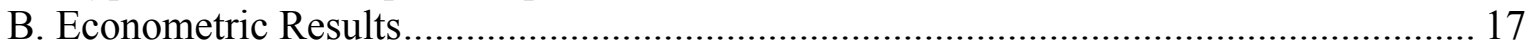

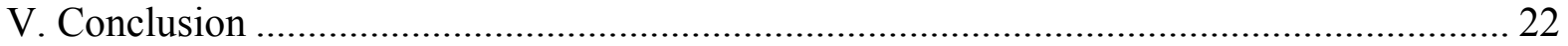




\section{INTRODUCTION}

The realization that hydrocarbon revenues are exhaustible, uncertain, and volatile has led to a growing consensus in the Middle East that governments must diversify their tax revenue sources, which tend to be highly dependent on the hydrocarbon sector. For example, according to 2006 IMF Article IV reports on Syria and Yemen, at current extraction rates, oil would run out in a few years, making tax reforms to replace declining oil revenues urgent. For countries with large oil or gas reserves, such as Saudi Arabia, raising tax revenues is less urgent, though still necessary for longer-run fiscal sustainability.

Raising taxes in the Middle East is, however, hampered by both a complex tax system and widespread corruption. Complex and fragmented tax administration has its source in part in British and French traditions. Contrary to current best practices, in some Middle Eastern countries, the treasury rather than a separate tax administration collects taxes; in others, direct taxes and indirect taxes are collected by different agencies (see Crandall and Bodin, 2005). Such dispersed systems of tax administration make it difficult to enforce taxpayer compliance, though this is not to deny that the Middle East in general, and some countries like Morocco and Tunisia in particular, have made great strides in improving tax administration.

The other reason for low tax revenues is widespread institutional corruption; the widely cited annual Transparency International Corruption Perception Index (TICPI) in 2005 gave the Middle East as a whole a value of 3.8 and the non-Gulf countries an even lower 2.9 out of a possible $10 .^{2}$ True, institutional corruption is not unique to the Middle East. The phenomenon is widespread in tax and customs administrations in many developing countries, including most Sub-Saharan African countries and many countries in Latin America and Asia. However, between 2000 and 2005 the TICPI ranking of the Middle East as a whole actually

\footnotetext{
${ }^{2}$ The Transparency International index is based on the opinion of experts. It intends to capture the extent to which "high government officials are likely to demand special payments" and "illegal payments are generally expected throughout lower levels of government" in the form of "bribes connected with import and export licenses, exchange controls, tax assessments, police protection, or loans."
} 
deteriorated, from 4.4 to $3.8 .^{3}$ Even if we only look at countries for which data are available for both 2000 and 2005, the indicator worsened slightly, to 4.3 in 2005.

The TICPI statistics might suggest that the Middle East has until now not recognized the problem that corruption poses for tax and custom administrations. This is misleading. Countries in the region have implemented or are now implementing institutional reforms that are critical first steps to reduce corruption. For instance:

- Many countries, such as Egypt, Jordan, and Lebanon have established function-based, integrated tax administrations, and Francophone countries, such as Algeria and Morocco, have had a function-based tax administration since the early 1990s.

- Many countries (e.g. Algeria, Egypt, Lebanon, Morocco and Tunisia) have introduced self-assessment procedures, which are critical to reduce contacts (and opportunities for negotiation) between taxpayers and tax officers.

- The introduction of information technology may also have been helpful in reducing face-to-face contacts between tax payers and tax officials. These new technologies allow for filing and payment systems to take place through banks (e.g. Morocco and Lebanon) or for large taxpayers directly, while other countries are beginning to implement such electronic filing and payment systems, initially focusing mainly on large taxpayers (e.g. Egypt, Tunisia and Morocco).

- Finally, some countries have significantly modernized customs procedures, such as simplified clearance processes and selective post-clearance audits (e.g. Jordan, Lebanon and Morocco), again with the intention of reducing opportunities for corruption.

The issue therefore is not whether tax and customs administration reform is now a reality in the Middle East but rather whether it has gone far enough in reducing corruption.

\footnotetext{
${ }^{3}$ Comparisons between years should be viewed as indicative; some countries included in 2005 were not included in 2000 .
} 
Empirical evidence has shown that corruption reduces tax revenues (see Abed and Gupta, 2002, for a summary of explanatory studies). Based on these studies, the public finance literature has provided general recommendations to raise tax revenues, recommending such institutional reforms as reinforcing the role of the judiciary to limit corruption. These studies have, however, looked at the effect of corruption on tax revenues in general, lumping all taxes together. This ignores the fact that different taxes are likely to be affected differently by corruption. The aim of this paper is to look at what determines the revenue-generating capacity of specific taxes to see which are more susceptible to corruption. This would allow for policy conclusions to be drawn on how to diversify and raise tax revenues more effectively, which in turn may inform government with policy choices, such as to switch to taxes that are less susceptible to corruption or to undertake to tackle corruption directly. ${ }^{4}$

We urge the reader to be cautious about interpreting our findings. The paper deals with the Middle East as a whole. Its conclusions therefore do not necessarily reflect any particular national situation - there are a wide variety in the region. In reality, tax and custom administration reform is now a reality in many Middle Eastern and North African countries.

In what follows, Section II briefly reviews the problems corruption poses for revenue administration. Section III describes the current revenue structure in the Middle East generally, and Section IV describes the results of an empirical study to estimate the impact of corruption on the revenue-generating capacity of different taxes in the region. Section V outlines possible reforms of the revenue system and administration.

\section{Corruption in Revenue Administration}

For this study, we define institutional corruption as an unlawful or unauthorized act engaged in by a public official using his or her position to receive a bribe, directly or through a family member or associate, in exchange for making a benefit available to a member of the public

\footnotetext{
${ }^{4}$ It could still be possible to raise considerable revenue from a tax, even if more could be raised if corruption were lower. Conversely, a tax such as an excise tax (e.g., on playing cards) may not vulnerable to corruption but also may never be lucrative. However, such a tax could is highly distortionary and should possibly be shunned.
} 
(e.g., a taxpayer). Opportunities for corruption in revenue administration are affected by demand from companies and individuals for corrupt actions and the supply by tax officials of corrupt acts. Demand for corruption increases with the complexity of tax systems, for instance, while supply could increase, for example, if the law gives tax officials excessive discretion.

Corruption is a multidimensional problem. General factors leading to corruption within a country have to be differentiated from specific factors that affect corruption within the revenue administration in particular. Factors affecting corruption generally range from the size of the government in the economy to officials with excessive discretion to inadequate control systems with limited accountability to cultural norms. Specific factors affecting corruption in the tax administration are numerous, but tend to have as a common denominator frequent interactions between the tax administration and individuals. They can occur in, among other areas, collection, enforcement of arrears collection, appeals, and even customer service, such as selling taxpayer information and issuing tax identification numbers and cards to fictitious taxpayers. ${ }^{5}$

The effect of corruption on tax revenue has to be qualified, however. Corruption sometimes does not involve taxpayers and may not always affect tax revenue directly. For example, when tax auditor positions in a revenue administration are "sold" instead of being filled through proper selection process, the taxpayer is not directly involved. Similarly, if a taxpayer bribes a revenue administration employee to expedite processing of a tax refund, this does not necessarily entail a loss of tax revenue (except in present value terms).

To analyze the problem of corruption in revenue administration, the main causes or motivations need to be explored. Such an examination could yield valuable suggestions for

\footnotetext{
${ }^{5}$ Among the possible forms of corruption in revenue administration, corruption in revenue audit may have the greatest negative impact on collections (Dos Santos, 1995). Corrupt practices that occur when a taxpayer being audited could be preceded by tax evasion or understatement of revenue, partly because this is an environment where negotiating tax liabilities is the norm. A taxpayer not fearing the consequences of being caught will, in many countries, decide to evade taxes in the belief that even if tax officials detect the evasion, the tax auditor can be bribed and payment of the proper tax liability avoided.
} 
preventing corruption. Setting ethical considerations aside, corruption would appear to be determined primarily by the following causes or motivations (Dos Santos, 1995; Tanzi, 1998; Keen, 2003):

\section{Factors Related to the Tax System}

- A complex tax system can facilitate corruption. Tax auditors may extort bribes from taxpayers by taking advantage of complex rules or exercising the excessive discretion they have because of unclear laws, regulations, and procedures. The taxpayer, who may well be evading taxes, may choose to bribe the auditor rather than report the extortion to the revenue administration.

- $\quad$ High tax rates may lead to more corruption by increasing the incentive for taxpayers to evade them; however, there is no clear evidence to either validate or refute this. ${ }^{6}$

- $\quad$ Lack of sanctions is another important factor stimulating corruption. The likelihood of corruption increases if penalties are not sufficiently severe (immediate dismissal and criminal charges) or seldom imposed.

- When it is time-consuming and costly to appeal, the taxpayer might resort to corrupt behavior simply to get things done.

\section{Factors Related to Tax Administration}

- When it is complex and cumbersome to pay taxes, the temptation for corruption as a short cut could arise, to both save time and reduce uncertainty about how much tax to pay.

\footnotetext{
${ }^{6}$ Theory does not even provide a clear answer about the relationship between tax rates and the degree of compliance. If the fine on being caught depends on the amount of income or the amount of tax concealed, reducing tax rates may lead to an increase or decrease in compliance (see Ivanova, Keen, and Klemm, 2005, for a literature review).

${ }^{7}$ Another possible reason for corruption in the tax administration could be pleasure in "beating the system." This motivates some people who believe they are "smarter than the rest" and boast to their friends that they are bribing the tax auditors. But evidence for this proposition is weak.
} 
- When deciding on whether to engage in corruption, individuals take into account their perceived risk of detection and punishment. If they feel that systems are deficient (the risk is low), they are more likely to engage in corrupt practices.

- If wages of revenue administration personnel are very low, corruption may be considered an acceptable way to supplement income.

\section{Behavioral or Cultural Factors}

- In organizations where corruption is endemic, honest employees may be led into corruption by the behavior of others. Corrupt employees also exert pressure when they will not accept that someone in the group should behave properly while others are engaging in corrupt practices. If senior revenue administration officials are known to engage in corrupt practices, lower-level employees have another justification to engage in similar practices.

Evidence from around the world has made it clear that corruption in revenue administration is a serious problem. In some countries, like Peru and Uganda, corruption in the tax administration was so endemic that the government closed it down and started a new one. In many developing countries applications for poorly paid customs jobs are far higher than for similarly paid government jobs, which suggests applicants saw as possibility of making extra money (Abed and Gupta, 2002). Anecdotal evidence has shown that where revenue administration processes have been modernized, as through the creation of a fully functional Large Taxpayer Office (LTO) and the computerization of customs procedures, revenue collections have improved and corruption has been reduced (Dos Santos, 1995).

\section{COMParison OF TAXation Systems In Middle East Countries}

To establish whether specific types of tax are indeed prone to corruption, it is useful to first analyze how governments in the Middle East finance themselves. In this study, the Middle East is defined as Algeria, Bahrain, Comoros, Djibouti, Jordan, Kuwait, Lebanon, Libya, Mauritania, Morocco, Oman, Qatar, Saudi Arabia, Sudan, Syria, Tunisia, and the United Arab Emirates; Iraq, Palestine, and Somalia are excluded for lack of data. 
In terms of share of GDP, whether looking at direct or indirect taxes the Middle East as a whole is not highly taxed (see Appendix 1 for a comparison with other regions in terms of tax revenue collection as a share of GDP). There are, however, huge variations between countries on the amount of tax and on which taxes generate most government revenue as a share of GDP.

The revenue structure of governments in the Middle East region is largely a function of the availability of hydrocarbons: countries with large oil and gas reserves (e.g., Libya) rely mainly on oil and gas royalties and profit taxation; those lacking hydrocarbons (e.g. Morocco) rely on taxation of non-hydrocarbon resources (Figure 1). Generally speaking, large oil- producing Gulf Cooperation Council (GCC) countries have little (sometimes no) direct taxation, relying mostly on hydrocarbons and, to a lesser extent, nontax income for government revenue. In these countries, direct and indirect taxes and nontax revenues account for only a small share of government revenues.

FIGURE 1: COMPARISON OF SOURCES OF GOVERNMENT REVENUE FOR MIDDLE EASTERN COUNTRIES, 2004

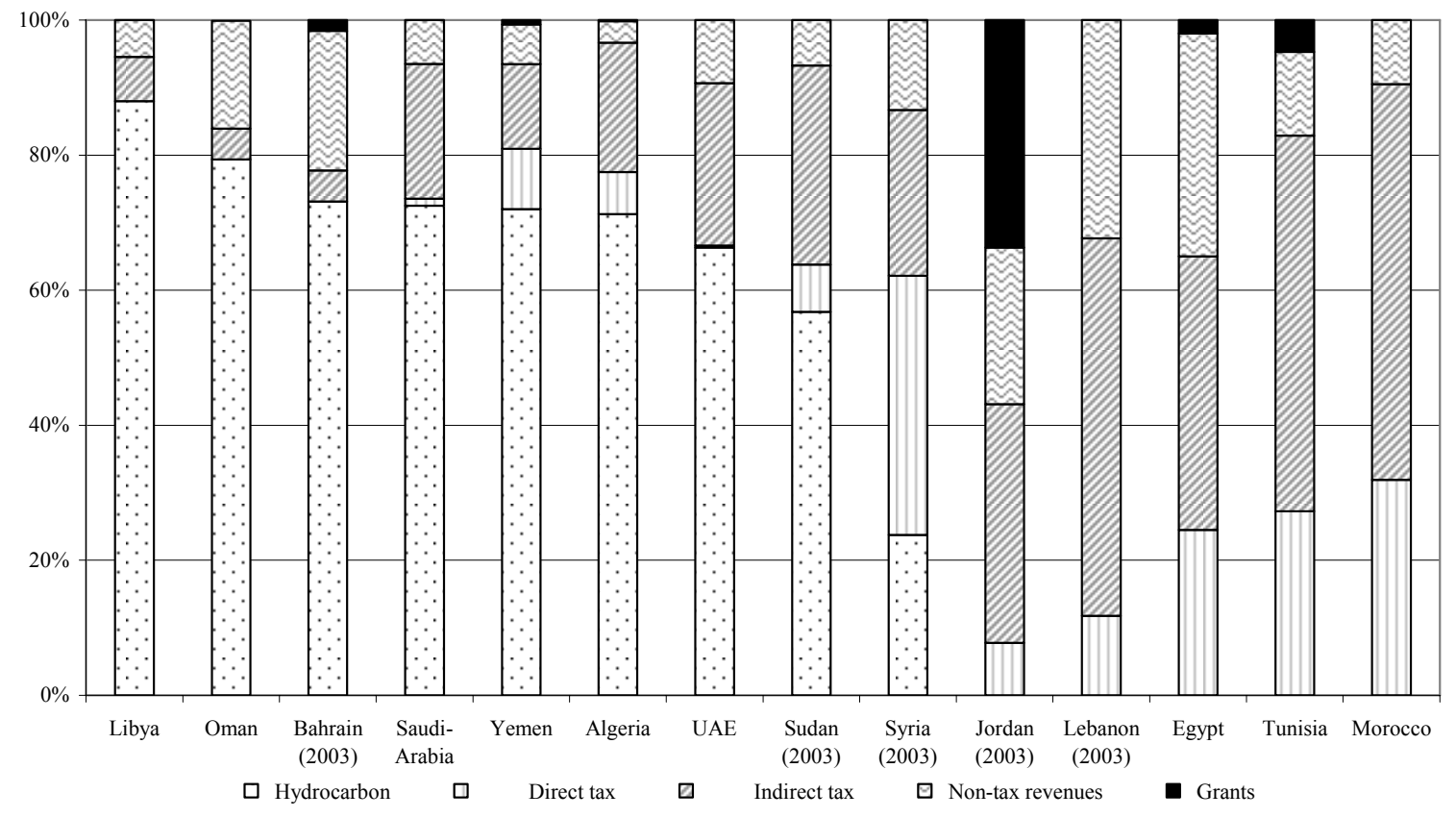

Source: IMF Article IV (2004) and (2005) 
Middle East countries that produce little or no hydrocarbons, such as Jordan and Lebanon, rely mainly on indirect taxation and nontax revenues, with few direct taxes . Morocco, Tunisia, and to a lesser extent Egypt (the latter two have some hydrocarbons) stand out for their reliance on direct taxes (over 20 percent), in part because their tax administration is relatively well developed.

This pattern of taxation is not surprising.

1. Some low or not hydrocarbon Middle East countries have large agricultural and service sectors, which are often informal and rely on low-income day laborers who are paid irregularly. As a result, the formal sector is small; this, combined with a low tax base, makes it difficult to rely on modern systems such as personal income tax (see Tanzi and Zee, 2000).

2. Raising revenues from direct taxation depends on the size and the economic and political strength of the middle class. Direct taxation is difficult to collect in lowincome countries where the poor have little taxable income and the rich and large enterprises are politically well connected and can lobby the government for either low tax rates and tax exemptions. In those countries indirect taxation (including trade taxes) becomes one of the main sources of government revenue because they can be implemented with relatively less political cost (see Tanzi and Zee, 2000).

3. Given that the tax administration is often of relatively low quality in relation to income (Crandall and Bodin, 2005), many Middle East countries have until now relied predominantly on a few revenue sources that are easy to tax, such as foreign trade taxes (Baer, Benon, and Toro, 2002). More effective tax administration could bring in more tax revenues in both non-hydrocarbon (and hydrocarbon) producing Middle East countries

The level of taxation as a share of GDP is low in hydrocarbon-producing countries, but high in other Middle Eastern countries (Figure 2). Countries that produce little or no hydrocarbons, such as Lebanon, Morocco, Jordan, Tunisia, and Egypt, have a share of nonhydrocarbon tax revenues of over 20 percent of GDP. On the other hand, while 
hydrocarbon-producing countries tend to have a large share of government expenditure to GDP (30 to 40 percent), the share of taxation is much lower given the availability of hydrocarbon revenues. Most hydrocarbon economies have a low share of nonhydrocarbon revenues of about 10 percent of GDP. As oil run outs in the coming decades, this situation is likely to change, and tax reforms are likely to be implemented across the region.

FIGURE 2: GOVERNMENT TAXATION AS A SHARE OF GDP IN 2004

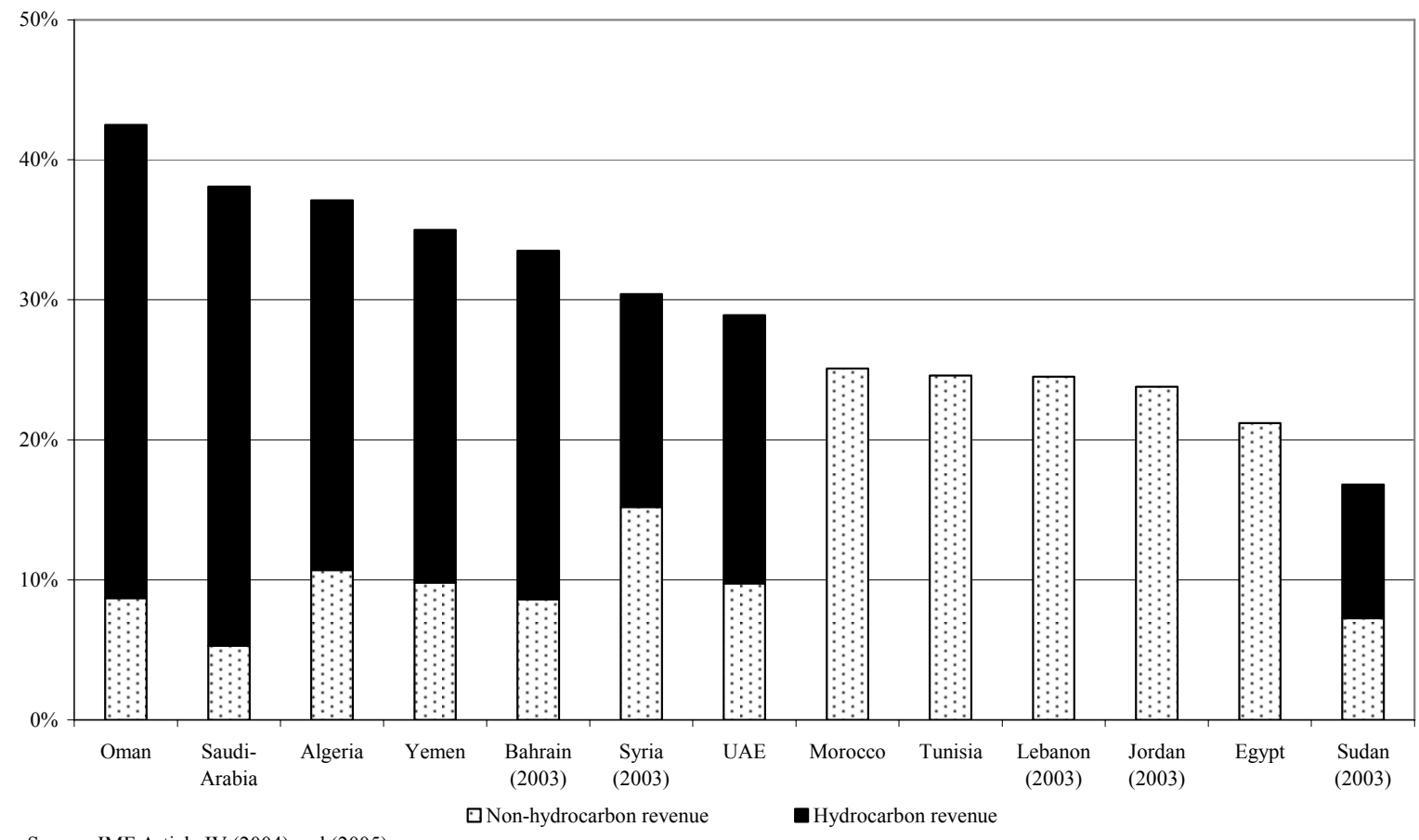

Source: IMF Article IV (2004) and (2005)

This finding is confirmed by looking at the ratio of nonhydrocarbon taxes to nonhydrocarbon GDP, which is considered a better proxy for how highly taxed an economy really is. It shows that nonhydrocarbon economies tax their populations on average two to three times more heavily than oil-producing countries. As can be seen from Figure 3, for countries with no (Morocco and Jordan) or limited hydrocarbons (Egypt, Tunisia, and Syria) the ratio is about 25 percent; for countries with large hydrocarbon reserves, the ratio tends to be less than 5 percent. Lebanon is the only outlier, because it has relatively high average income per person and relatively low tax rates. Critics could argue that this measure is biased: taxes like custom duties that are not paid directly by residents should not be regarded as taxes levied on the 
population. Given that these custom duties are passed on to domestic consumers, however, this problem is not as important as it appears at first, and the bias is therefore mitigated.

FIGURE 3: NON-HYDROCARBON GOVERNMENT TAXATION AS A SHARE OF NONHYDROCARBON GDP IN 2004

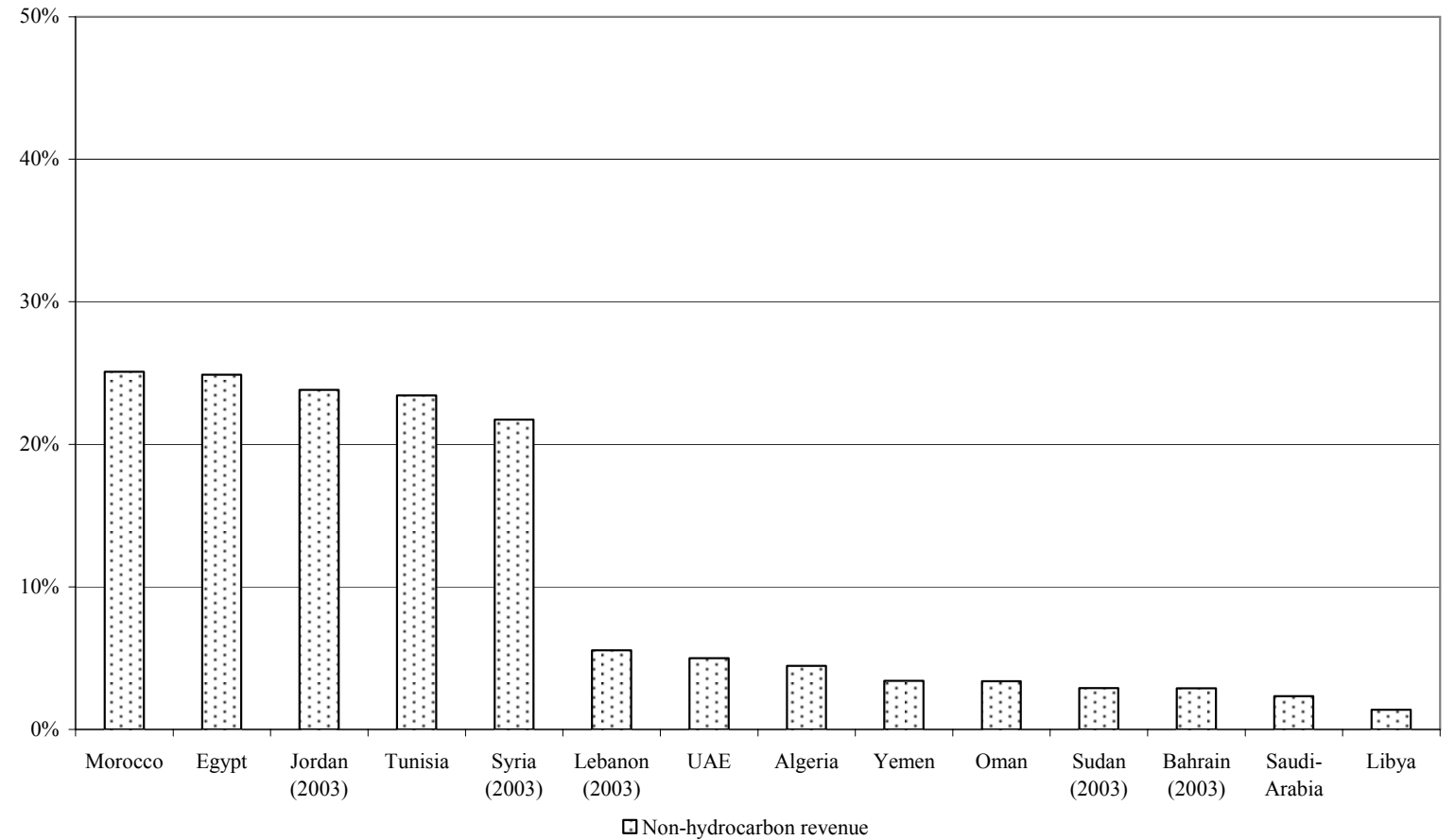

Source: IMF Article IV (2004) and (2005)

To maintain fiscal sustainability in the longer run, removing dependence on oil smoothly by diversifying sources of tax revenues away from hydrocarbons would therefore be an appropriate strategy, because

1. The Middle East as a region is not, by any commonly accepted standard, highly taxed relative to other regions at similar income levels (see Appendix 1; Keen and Simeone, 2004).

2. The rising number of free trade agreements (FTAs) within the region will eliminate an important source of tax revenues, another reminder of the need to diversify the tax base.

3. Hydrocarbon revenues, which are in any case highly volatile, will eventually run out and will eventually need to be replaced. Related, and perhaps most importantly, it is 
necessary to take into account not only current nonhydrocarbon revenues but also the desired future level of government expenditures within a context of fiscal sustainability. Given the population growth, these economies are bound to see a large expansion of government spending that will require more government revenues.

To raise the tax base, governments in the region must therefore take into account the relatively high corruption already described. The next section reports on our empirical study of which taxes can yield more revenues by simply reducing the incidence of corrupt revenue administration.

\section{EMPIRICAL STUDY}

To our knowledge, this is the first study to look at the effect of corruption on revenues from individual taxes, rather than on total tax revenues. Some studies have shown that corruption negatively affects overall revenue from taxation. Papers by Tanzi and Davoodi (1997) and Friedman, Johnson, Kaufmann, and Zoido-Lobaton (2000), for example, have provided evidence that countries with more corruption tend to collect fewer tax revenues in relation to GDP, all else being equal.

A problem affecting all the studies measuring the impact of corruption on tax revenue is that corruption is difficult to detect and quantify because by its very nature, it is illegal and secretive. This problem is worsened by the fact that corruption can mean different things in different cultures. But while there is indeed some ambiguity about how to define corruption globally, there are abuses of public positions that would be considered corrupt in all cultures, such as tax officials soliciting bribes from private individuals to reduce their tax bills.

Researchers have tried to quantify corruption by relying on surveys. One method is to survey either experts (the International Country Risk Guide) or firms (the Global Competitiveness Report Corruption Index). An obvious weakness of these measures is that perception does not necessarily equal the actual level of corruption; perception may be better but is often worse than reality. An alternative is to use a composite index made up of several expert and firm surveys. For example, the Transparency International corruption index is based on an 
average of different surveys. It is possible, of course, that different surveys may have the same perception bias, leaving us with a biased estimate. For instance, Wei (1997) finds that the correlation between the Business International Index and Transparency International, two of the most common measures of corruption, is 0.88 . This high correlation suggests that statistical inference on the consequences of corruption is not very sensitive to the choice of index. If, however, the corruption indices share the same bias, they may be highly correlated with each other but not with the true level of corruption. While this criticism is valid, it is likely that perception and reality are highly correlated. Nonetheless, these potential weaknesses suggest that we have to interpret our results carefully.

Ideally, the effect of corruption on different taxes should be tested for each country individually, but the scarcity of long time-series data on individual taxes for individual countries makes it impossible to draw robust statistical inferences by looking at only one country. Instead, general conclusions must be drawn by generalizing the results from running panels that cover the Middle East as a whole - more observations give us more reliable estimates.

\section{A. Hypothesis and Empirical Specification}

This section attempts to estimate corruption affects the revenue generated by

(i) all taxes together

(ii) taxes on income, profit, and capital gains

(iii) taxes on individuals

(iv) corporate and other enterprise taxes

(v) taxes on payroll and workforce

(vi) taxes on property

(vii) taxes on goods and services

(viii) taxes on excise and taxes on specific services

(ix) international trade taxes

(x) customs and other import duties

(xi) taxes on exports

(xii) social contribution taxes. ${ }^{8}$

\footnotetext{
${ }^{8}$ Attempts to estimate the difference between the official tax rate (the de jure rate) and the effective tax rate (the de facto rate), as a measure of the corruption level was not possible for lack of data.
} 
Both theoretical work and the literature on taxation (see Tanzi and Zee, 2000, for a good summary) lead to the hypothesis that the revenue-generating capacity of different taxes in the economy is determined by the following independent variables.

- Real income per capita: All else being equal, a higher income per capita level is likely to lead to higher revenues from all taxes.

- $\quad$ Share of agriculture in economy: The sectoral composition of an economy affects its ability to raise taxes. Agriculture in poorer countries is generally a subsistence activity, so countries dominated by this sector may be expected to raise less revenue.

- Openness: An economy that is open may be expected to raise more taxes because an economy with a large international trade sector tends to be one that is well organized and monetized, so the costs of tax administration is likely to be lower. There is one exception, however. Taxes related to international trade are likely to be lower in open economies because these governments try to minimize taxes to stimulate trade (see Rodriguez and Rodrik, 1999, for a critical review of the effect of openness on growth and taxation).

- Inflation: This variable captures the effect of macroeconomic policies. The worse the macroeconomic situation, the lower the revenues from different taxes.

- $\quad$ Corruption: More corruption will result in lower revenue from all taxes.

These factors lead to the formulation of the following panel regression:

$$
\frac{\operatorname{Tax}_{i j}}{G D P}=\alpha_{i t}+\beta_{1 j} \ln Y_{i t}+\beta_{2 j} A G R_{i t}+\beta_{3 j} O P E N_{i t}+\beta_{4 j} C P I_{i t}+\beta_{5 j} C O R R_{i t}+\eta_{i j}+\mu_{i j}+\varepsilon_{i t j}
$$

where $i=$ country, $t=$ year, and $j=$ the coefficient, which can differ across taxes. 
In the regression, $\frac{\operatorname{Tax}_{i j} "}{G D P_{i t}}$ is nonhydrocarbon tax revenue relative to nonhydrocarbon GDP for each different $\operatorname{tax}^{9} ; \ln Y$ is the natural logarithm of real income per capita, and $A G R$ represents the share of the agricultural sector in GDP. OPEN is a proxy for the degree of openness of the economy to the rest of the world, CPI is the Consumer Price Index, and CORR stands for corruption for each country. The variable $\eta_{i j}$ stands for the country effect and $\mu_{t j}$ for the time effect. The error term $\varepsilon_{i j}$ is assumed to be identically and independently distributed over countries and years. (See Appendix 2 for descriptions and data sources.)

We will not use a simple fixed effect panel regression to estimate the equation because it might be beset by model uncertainty (e.g., omitted variables) and inconsistent empirical estimates (e.g., endogeneity problems). Model uncertainty can arise when we cannot fully identify the determinants of tax revenues. For example, if the specification model ignores factors that might affect tax compliance, such as social capital, we might have misspecification of the model. Inconsistent estimates will arise if, for example, right-handside variables are assumed to be exogenous but are in fact endogenous. To address these two problems, endogeneity and potential omitted variables bias, we will use the system-GMM (generalized-method-of-moments) panel estimator. System-GMM helps control for possible specification bias when variables are highly persistent over time and for possible simultaneity bias. We do not use the first-differenced GMM estimator; Bond, Hoeffler, and Temple (2001) and Blundell and Bond (1998) show that it performs poorly in finite samples and produces biased coefficients if the sample size is small or if the time series is highly persistent. They demonstrate, on the other hand, that the system-GMM estimator produces large increases in both consistency and efficiency.

The proxy for corruption used is the International Country Risk Guide (ICRG). Indices such as those of Transparency International and the World Development Report are

\footnotetext{
${ }^{9}$ Using non-hydrocarbon taxes to non-hydrocarbon GDP is deemed a better measure for the taxation level of the population. The results do not change in any significant way when using overall taxes to overall GDP. These results are available on request from the authors.
} 
comprehensive only for recent years; they tend not to cover our countries of interest before 1995. The only known index that covers most Middle Eastern countries since the early 1990s is the ICRG Corruption Index produced annually by Political Risk Services. The ICRG index ranges from 0 (most corrupt) to 6 (least corrupt), so to make interpretation easier it was rescaled by multiplying it by $10 / 6$ so that the index ranges from 0 to 10 . This index was then multiplied by minus one so that when the regression is run, higher values will mean more corruption.

The aim of our analysis is to regress the 11 different taxes on the different independent variables including corruption in the Middle East and see which taxes are more susceptible to corruption. We carried out a system-GMM estimation for the 1990-2003 period in 12 countries: Algeria, Bahrain, Egypt, Jordan, Lebanon, Morocco, Oman, Sudan, Syria, Tunisia, United Arab Emirates, and Yemen. The other Middle Eastern countries were excluded for lack of data. Table 1 gives the regression results.

\section{B. Econometric Results}

Before analyzing our results, we should test for the validity of the instrument used in our system-GMM using the Sargan test, which checks for overidentifying restrictions. The hypothesis it is testing is that the instrumental variables are uncorrelated to some set of residuals and therefore are acceptable instruments. The Sargan test for all cases have large pvalues, suggesting that the overidentifying restrictions should not be rejected.

As expected, the various taxes are not equally affected by income per capita, share of agriculture, openness, inflation, and corruption because different taxes have different determinants. Income taxes, for example, are more influenced by average income per capita than by openness, and export taxes are more affected by openness than by inflation. This confirms that for certain taxes, the regressors explain much of the variation in the dependent variable, but for others they do not. 


\begin{tabular}{|c|c|c|c|c|c|c|}
\hline $\begin{array}{c}\text { Dependent Variable (in percent on } \\
\text { non-hydrocarbon GDP) }\end{array}$ & Total Tax Revenue & $\begin{array}{c}\text { Taxes on Income, Profits, and } \\
\text { Capital Gains }\end{array}$ & Taxes on Individuals & $\begin{array}{c}\text { Corporation and Other } \\
\text { Enterprise Taxes }\end{array}$ & $\begin{array}{c}\text { Taxes on Payroll and } \\
\text { Workforce }\end{array}$ & Taxes on Property \\
\hline \multirow[t]{2}{*}{ Constant } & $173.990\left(^{* * *}\right)$ & $44.142(* *)$ & $-27.509\left({ }^{* * *}\right)$ & $6.894\left(^{* * *}\right)$ & $-1.432\left({ }^{* * *}\right)$ & 0.737 \\
\hline & (32.135) & (17.054) & (3.079) & $(2.630)$ & $(0.331)$ & $(0.626)$ \\
\hline \multirow[t]{2}{*}{ In Real Income per capita (US\$) } & $-21.626\left({ }^{* * *}\right)$ & $\left.5.055^{* *}\right)$ & $4.094\left(^{* * *}\right)$ & -0.479 & 0.053 & -0.042 \\
\hline & $(4.501)$ & (2.389) & $(0.416)$ & $(0.305)$ & $(0.046)$ & $(0.087)$ \\
\hline \multirow[t]{2}{*}{ Share of agriculture in GDP } & 0.026 & -0.120 & $-0.088\left(^{(* *)}\right.$ & -0.048 & $0.018(* * *)$ & $-0.019(* *)$ \\
\hline & $(0.241)$ & $(0.128)$ & $(0.022)$ & $(0.036)$ & $(0.004)$ & $(0.008)$ \\
\hline \multirow{2}{*}{ Openness } & -0.028 & -0.003 & $0.007(* * *)$ & -0.005 & $0.004\left(^{* * *}\right)$ & $-0.000(* *)$ \\
\hline & (0.029) & $(0.015)$ & $(0.003)$ & $(0.007)$ & $(0.001)$ & $(0.002)$ \\
\hline \multirow{2}{*}{ Inflation } & $0.115\left(^{(* *)}\right.$ & 0.023 & $-0.008\left(^{* * *}\right)$ & $-0.015\left(^{*}\right)$ & $0.005(* *)$ & -0.002 \\
\hline & $(0.029)$ & $(0.015)$ & $(0.003)$ & $(0.009)$ & $(0.001)$ & $(0.002)$ \\
\hline \multirow[t]{2}{*}{ Corruption } & 0.982 & -0.345 & 0.008 & $-0.405\left(^{*}\right)$ & $-0.072(*)$ & -0.143 \\
\hline & $(0.603)$ & $(0.320)$ & $(0.052)$ & $(0.228)$ & $(0.037)$ & $(0.064)$ \\
\hline Sargan test (p-value) & 0.336 & 0.137 & 0.630 & 0.630 & 0.993 & 0.328 \\
\hline No. of Observations & 88 & 88 & 88 & 87 & 88 & 88 \\
\hline \multicolumn{7}{|c|}{$\left({ }^{*}\right),\left({ }^{* *}\right)$, and $\left({ }^{* * *}\right)$ denote, respectively, significance at the $1 \%, 5 \%$ and $10 \%$ levels. } \\
\hline $\begin{array}{c}\text { Dependent Variable (in percent on } \\
\text { non-hydrocarbon GDP) }\end{array}$ & $\begin{array}{c}\text { Taxes on Goods and } \\
\text { Services }\end{array}$ & $\begin{array}{c}\text { Taxes on Excise and Taxes on } \\
\text { Specific Services }\end{array}$ & $\begin{array}{c}\text { International Trade } \\
\text { Taxes }\end{array}$ & $\begin{array}{l}\text { Taxes on Customs and } \\
\text { Other Import Duties }\end{array}$ & Taxes on Exports & $\begin{array}{l}\text { Taxes Social } \\
\text { Contributions } \\
\end{array}$ \\
\hline \multirow[t]{2}{*}{ Constant } & $-51.818(* *)$ & -1.428 & $56.937\left(^{* * *}\right)$ & $56.063\left(^{* * *}\right)$ & -0.203 & $-10.989\left(^{*}\right)$ \\
\hline & (10.619) & (11.568) & (11.364) & (11.257) & $(0.409)$ & (5.899) \\
\hline \multirow[t]{2}{*}{ In Real Income per capita (US\$) } & $8.8577^{(* * *)}$ & -0.304 & $-8.501\left(^{* * *}\right)$ & $-8.355\left(^{* * *}\right)$ & 0.002 & $1.909\left(^{* *}\right)$ \\
\hline & (1.488) & $(1.609)$ & (1.592) & (1.577) & $(0.057)$ & (0.826) \\
\hline \multirow[t]{2}{*}{ Share of agriculture in GDP } & $-0.269_{(* * *)}^{*}$ & 0.131 & $\left.0.3588^{* * *}\right)$ & $\left.0.3499^{* * *}\right)$ & $\left.0.0099^{* * *}\right)$ & $-0.107(*)$ \\
\hline & $(0.076)$ & $(0.089)$ & $(0.085)$ & $(0.084)$ & $(0.003)$ & $(0.044)$ \\
\hline \multirow[t]{2}{*}{ Openness } & -0.007 & 0.13 & -0.001 & -0.002 & 0.001 & 0.008 \\
\hline & $(0.010)$ & $(0.010)$ & $(0.010)$ & $(0.010)$ & $(0.001)$ & (0.005) \\
\hline \multirow[t]{2}{*}{ Inflation } & $-0.016\left(^{*}\right)$ & 0.008 & 0.013 & 0.011 & $\left.0.0011^{* *}\right)$ & $-0.012(* *)$ \\
\hline & $(0.010)$ & $(0.011)$ & $(0.010)$ & $(0.010)$ & $(0.001)$ & $(0.005)$ \\
\hline \multirow[t]{2}{*}{ Corruption } & $-0.378\left(^{*}\right)$ & $0.783(* * *)$ & $0.959\left({ }^{* * *}\right)$ & $0.936(* * *)$ & $0.2011^{(* *}$ & 0.127 \\
\hline & $(0.199)$ & $(0.217)$ & $(0.213)$ & $(0.211)$ & $(0.008)$ & $(0.111)$ \\
\hline Sargan test ( $p$-value) & 0.458 & 0.182 & 0.519 & 0.517 & 0.171 & 0.153 \\
\hline No. of Observations & 88 & 88 & 88 & 88 & 88 & 88 \\
\hline
\end{tabular}

Our regression results suggest that most tax revenues are not very responsive to changes in nonhydrocarbon income. Only taxes that might be expected to be highly elastic to income changes, such as those on individuals, appear to be statistically significantly affected by income changes. This may reflect several factors. First, the governments rely very little on nonhydrocarbon tax revenues. Second, these taxes might be applied to goods that do not change much with income growth, such as basic necessities, or be lump sum rather than proportional taxes. High income inequality might also explain the low elasticity of tax revenues to nonhydrocarbon income.

Overall, the bigger the share of the agricultural sector in the economy, the lower the total tax revenue. The exception is taxes related directly to the agricultural sector, with countries that have a higher share of agriculture in the economy enjoying higher income taxes. This might simply reflect the fact that governments tax the trade sector more when the economy is less developed because it is administratively easy to collect there. 
The degree of openness and inflation do not have a systematic effect on most taxes. Openness seems to be an insignificant factor in revenue collection for most taxes, probably because few taxes are directly affected by the openness of an economy. That real tax proceeds are eroded during periods of higher inflation (the Tanzi effect) is in most cases not apparent; on most taxes collected, any inflation impact is likely to be positive. This could be because the countries in our sample have relatively stable economies. Alternatively, the lag in payment of taxes in many countries in the Middle East is not long, which would limit the Tanzi effect.

Corruption does not have a statistically significant impact on total tax revenues in the Middle East. This is not surprising (see Section II). There are several determinants of corruption, which might affect the collection of diverse taxes differently. We did not necessarily expect that by lumping all tax revenues together we would find a positive relation between corruption and tax revenues. The real effect of corruption should be looked at by analyzing individual taxes instead.

When total taxes are broken down into individual ones, the results suggest that taxes requiring frequent interactions between tax authorities and individuals, namely trade taxes, are most affected by corruption. Taxes on exports, customs and other import duties, and international trade taxes," which are important sources of revenue in the Middle East, are all negatively and statistically significantly affected by corruption.

Why are trade taxes affected by corruption in the Middle East (see Crandall and Bodin, 2005 for evidence)?

1. They are often subject to outdated legislation, replete with rate differentiations and exemptions for various goods.

2. Because of outdated tax administration, control procedures require extensive physical inspection, leading to frequent interactions between individuals on high-volume and high-value products. 
3. Traders' costs of complying with border formalities are high, about 27 percent of the value of the shipment. Corrupting underpaid border guards who have substantial discretionary power can, for instance, avoid delays in clearance, which can add an estimated 10 percent in costs alone (Keen, 2003).

While most countries in the Middle East have seen improvements in strategy, law, procedures, and information technology in customs administration (Table 2), the organizational structure and institutional processes that are conductive to integrity and effectiveness in customs administrations have hardly improved (see also Keen, 2003). The need to reform tax administration has long been recognized, but in much of the Middle East,

Customs administrations have been hesitant to embrace modernization ... [because of] a general resistance to the inevitable organizational disruption that occurs in a modernization initiative [and due] to the impact that simplified procedures and transparent operations could have on opportunities for corruption and other rentseeking" [emphasis added] (Crandall and Bodin, 2005, p. 14).

It should be emphasized, however, that in future, revenues from trade taxes are likely to decline due to the increasing number of FTAs in the region, which suggests that corruption in the customs administration is likely to become less severe.

\begin{tabular}{|c|c|c|c|c|c|c|c|c|c|c|c|c|c|c|c|c|}
\hline & \multicolumn{2}{|c|}{ Algeria } & \multicolumn{2}{|c|}{ Egypt } & \multicolumn{2}{|c|}{ Jordan } & \multicolumn{2}{|c|}{ Lebanon } & \multicolumn{2}{|c|}{ Morocco } & \multicolumn{2}{|c|}{ Saudi Arabia } & \multicolumn{2}{|c|}{ Sudan } & \multicolumn{2}{|c|}{ Yemen } \\
\hline & $1990 \mathrm{~s}$ & Now & $1990 \mathrm{~s}$ & Now & $1990 \mathrm{~s}$ & Now & $1990 \mathrm{~s}$ & Now & $1990 \mathrm{~s}$ & Now & 1990s & Now & $1990 \mathrm{~s}$ & Now & 1990s & Now \\
\hline Custom Strategy & No & Yes & No & Yes & No & Yes & No & Yes & No & Yes & No & Yes & No & Plan & No & Yes \\
\hline Custom Law in Place & $\mathrm{RR}$ & 1 & A & 1 & A & 1 & A & 1 & A & 1 & C & $\mathrm{RR}$ & A & 1 & A & $\mathrm{RR}$ \\
\hline Effective Custom Procedures & C & MI & C & I & A & I & A & 1 & A & I & C & $\mathrm{MI}$ & Basic & 1 & C & 1 \\
\hline Post-Release Verification & No & No & No & No & No & 1 & No & 1 & No & Yes & No & No & No & No & No & MI \\
\hline Effective Organization & No & MI & No & 1 & No & 1 & No & I & No & Yes & No & $\mathrm{Ml}$ & No & No & No & No \\
\hline Information Technology usage & Poor & 1 & Good & 1 & Basic & ++ & Poor & Good & Basic & 1 & Basic & I & Basic & ++ & Poor & ++ \\
\hline Source: Crandall and Bodin (200 & & & & & & & & & & & & & & & & \\
\hline $\begin{array}{l}\text { A = Adequate } \\
\mathrm{C}=\text { Overly complex } \\
\mathrm{I}=\text { Improved } \\
\mathrm{MI}=\text { Minor improvements } \\
\mathrm{RR}=\text { Revision or review requir } \\
++=\text { Automated system for cus }\end{array}$ & & UDA & & & & & & & & & & & & & & \\
\hline
\end{tabular}

The other tax category affected by corruption is taxes on excise and on specific services. Excise taxes are imposed on the production of low-elasticity goods. Given that physical checks are common when excise taxes are imposed, the taxes provide incentives for corrupt tax practices similar to those found in the customs area. Persistent smuggling and other forms 
of tax evasion explain why corruption is common with excise taxes (e.g., on cigarettes). Individuals have considerable incentive to avoid heavy duties by resorting to these forms of corruption, reducing the collection capacity of this tax.

Direct taxes affecting corporations and individuals are not much affected by corruption; here it is either insignificant or barely significant at the 10 percent level. This is at first surprising. Direct taxes are usually thought as of being hard to collect when tax administration is not strong. The insignificant effect of corruption might be in part due to the introduction of Large Taxpayer Offices (LTOs) that focus on taxing a few rich individuals, state enterprises, and foreign multinationals whose activity is easily monitored. Many Middle Eastern countries have made progress in modernizing revenue administration. Jordan, for example, launched an integrated income tax LTO in October 2004 by segmenting taxpayers into large, medium, and small groups. Algeria and Egypt also recently launched integrated LTOs (see Ernst and Young, 2003, for a survey of modernization of the tax procedures in these countries).

Alternatively, the statistically insignificant effect of corruption on these taxes could simply be due to the fact that direct taxes are in general low, so compliance is higher.

For indirect taxes, from property taxes to taxes on goods and services, corruption also does not appear to have a statistically significant effect. Again this may be due to the fact that these taxes affect mainly formal activity, and accounts in the formal sector are relatively transparent.

The implications of these findings for the Middle East are as follows:

1. Corruption at the customs level is most harmful to revenue and needs to be reduced. While trade taxes as a share of GDP are not very large in the Middle East compared to other regions (see Appendix 1), their yield appears to be heavily affected by corruption. Corruption at the customs hurts not only tax revenues but also the capacity to trade. To diminish the propensity for corruption, governments should reduce exemptions, reduce trade taxes to rate differentiations, and complement these policies by reinforcing administrative capacity by reforming the structure of the 
revenue system. Paying administrators more will also reduce the attraction of corruption. The same issues apply to excise taxes.

2. Corruption does not seem to affect the ability of these governments to raise other forms of taxation. This should encourage them to introduce more direct taxes on individuals and corporations (but with a warning that raising them too much might lead to killing the golden goose) and indirect taxes, where corruption appears to be less pervasive in affecting tax revenues and which tend to raise a lot of government revenue as marginal income rises.

Interestingly, throughout the region governments have introduced or are now introducing indirect taxes in the form of general sales taxes (GST) or value-added taxes (VAT). Following the lead of Morocco and Tunisia in the late 1980s, Egypt in 1991 and more recently Jordan in 2001 have implement these taxes, and Yemen and Syria will soon do so. The GCC countries are also considering adopting the VAT but no decision has yet been made. Indirect taxes like a GST/VAT are considered less susceptible to corruption, since tax authorities have far less discretion, and they raise more revenues when marginal incomes rise.

Our findings have to be qualified. Just because the corruption variable does not appear to have a statistically significant impact on certain taxes does not necessarily mean that it does not affect their revenue-generating capacity. First, tax reforms in the Middle East between 1990 and 2003 may have caused structural breaks in different countries at different times that are not directly measured and adjusted for in the regression. Given that tax reforms take years to implement, it is difficult to use dummy variables because they often extend over the whole period of our sample. Second, the panels are not fully balanced, so that for some taxes in certain countries for some years, observations are sparse, making inference hazardous.

\section{Conclusion}

Tax and custom administration reform is now a reality in many Middle Eastern countries. The region has made great strides in the last decade in reforming its revenue administration. 
In coming years and decades as hydrocarbon revenues fall, however, further reforms are needed to replace them. As reforms are planned, there are several policy options that can minimize the effect of corruption on tax revenue. One involves a switch to taxes that are less susceptible to corruption. Another would be to combat corruption directly.

In considering the first option, governments can increase both direct and indirect taxes (especially in those countries expecting oil revenue to decline soon) to bring in more revenues over the medium term. Both direct and indirect taxes depend on a sophisticated tax system, so tax administration should be improved as they are raised. The constraint on increasing direct taxes significantly is that they is politically not easy to raise it due to the pressure of interest groups. Constraints on indirect taxes are lower, though they also require a sophisticated tax administration; because they affect everyone, collective action will be more difficult and the lobbying against them will be weaker. This may explain the decision of many of these countries to introduce GST/VAT recently or in the near future.

The results here suggest that government revenues from taxation could rise if corruption falls, especially with regard to trade and excise taxes. Building up customs administration should therefore be a high priority — although the rising number of FTAs, by reducing tax revenues, are themselves likely to diminish the effect of corruption. Excise tax revenues will rise as corruption falls, implying that tax authorities should closely monitor how excise taxes are collected.

As for fighting institutional corruption, it depends on one critical factor: the political commitment of the country's highest authorities to do so. There are a number of ways to reduce corruption in revenue administration.

An effective measure to reduce corruption is to change incentives within the revenue administration by hiring and training professional staff and by strengthening internal control systems. If an organization is tolerant of corruption, its employees eventually become accustomed to it and believe that it is alright to be corrupt. Reducing corruption could be achieved through making professional staff aware of the problems of corruption through training, orientation programs, talks, and seminars, and, above all, by example from the highest authorities. Also, incentives offered to employees may help lower corruption over 
time. For instance, one incentive is to pay professionals decently, giving them a wage they can live on. This must be combined with an effective sanction system, which might differentiate between different types of corruption. ${ }^{10}$ The system of sanctions should also be extended to anyone who corrupts, or attempts to corrupt, revenue administration employees.

Modernizing tax administration will provide more effective systems to reduce corruption and raise tax revenues. Mail and telephone communication should be the norm rather than personal contacts. Control systems must be improved in areas where the risk of corruption is highest. Whenever possible, computerized systems should be used, and a system for auditing computerized systems should be implemented to detect fraudulent changes to programs or files. For example, if tax compliance certificates are required by law, they should be issued automatically by the computer system.

Simplifying the tax system will also reduce opportunities for corruption. Whenever possible, the system should have few rates, few exemptions, readily determinable taxable bases, easyto-calculate tax liabilities, broad use of withholding, use of presumptive income schedules, use of minimum taxes, and clear rules. Tax officials should have little discretion. Not only would such a system reduce compliance costs, it would also reduce corruption problems.

Finally, corruption can be reduced through transparency. The media can be of help here. If the press can report corruption, officials will have less incentive to solicit bribes because the probability and costs of getting caught are likely to be higher. Other ways to improve transparency are to make revenues reported by companies in the hydrocarbon sector available to the public, such as by subscribing to the Extractive Industries Transparency Initiative (EITI) for hydrocarbon-producing countries. The EITI, launched in 2002, is now supported by a range of governments in both developed and developing countries, civil society groups, and industry. It requires that companies (including state-owned resource companies) report aggregate payments to government, and that government publish aggregate payments it has

\footnotetext{
${ }^{10}$ For instance, the punishment for an employee who accepts a bribe to expedite processing of a refund in the revenue administration may not be the same as the punishment for an auditor who accepts a bribe from a taxpayer to refrain from adjusting a tax liability. In both cases the revenue administration officials should be fired but the criminal sanctions could be different
} 
received, so that discrepancies are transparent. EITI reporting guidelines and reporting templates for country governments and international and national companies have been drafted.

None of the reforms to raise tax revenues or reduce corruption can be easily implemented. The Middle East has gone through many economic reforms over the recent past, many of which have yielded successes, but others of which have run into setbacks. While corruption in the tax administration it probably cannot be fully eliminated, it must be reduced. This demands a government that is committed to a strong revenue administration with a highly professional staff. 


\section{Appendix I: COMPARISON OF TAXES BY REGION ${ }^{11}$}

Table 1. Consolidated Central Government: Total Revenue by Region, 1990-2004 1/ 2/

\begin{tabular}{|c|c|c|c|c|c|c|c|c|c|c|c|c|c|c|c|}
\hline & 1990 & 1991 & 1992 & 1993 & 1994 & 1995 & 1996 & 1997 & 1998 & 1999 & 2000 & 2001 & 2002 & 2003 & 2004 \\
\hline OECD Countries & 30.95 & 31.53 & 31.84 & 31.94 & 32.47 & 31.82 & 32.44 & 32.46 & 32.39 & 33.79 & 34.15 & 34.35 & 34.19 & 34.92 & 34.06 \\
\hline African Countries & 22.43 & 22.28 & 22.15 & 23.98 & 22.24 & 24.95 & 25.35 & 23.11 & 22.60 & 23.30 & 24.05 & 24.63 & 24.67 & 28.13 & 33.16 \\
\hline Asian and Pacific Countries & 21.08 & 20.78 & 19.66 & 20.10 & 20.07 & 20.63 & 20.82 & 20.22 & 19.19 & 20.75 & 21.25 & 22.10 & 21.10 & 22.56 & 23.68 \\
\hline European Countries 3/ & 35.04 & 34.42 & 35.06 & 34.92 & 34.47 & 33.16 & 33.93 & 34.11 & 34.14 & 35.01 & 35.65 & 34.59 & 34.63 & 35.95 & 35.64 \\
\hline Middle East and Central Asian Countries & 29.51 & 25.35 & 24.61 & 26.24 & 25.96 & 25.88 & 25.85 & 25.31 & 23.42 & 22.33 & 25.03 & 24.96 & 29.30 & 24.73 & 23.50 \\
\hline Western Hemisphere Countries & 18.07 & 20.12 & 20.39 & 21.90 & 21.67 & 20.02 & 19.09 & 20.27 & 19.76 & 20.12 & 22.89 & 23.67 & 23.50 & 25.52 & 25.51 \\
\hline Unweighted average 4/ & 26.18 & 25.75 & 25.62 & 26.51 & 26.15 & 26.07 & 26.25 & 25.91 & 25.25 & 25.88 & 27.17 & 27.38 & 27.90 & 28.64 & 29.26 \\
\hline
\end{tabular}

Sources: Government Finance Statistics (IMF); International Financial Statistics (IMF); and World Economic Outlook (IMF).

1/ When the data are not reported as Consolidated Central Government we used General or Budgetary Central Governemnt.

2/ Including grants and social contributions.

3/ Including OECD countries.

4/ For each revenue classification, only countries for which data are available are included in the calculation

Table 2. Consolidated Central Government: Total Tax Revenue by Region, 1990-2004 1/

(In percent of GDP)

\begin{tabular}{|c|c|c|c|c|c|c|c|c|c|c|c|c|c|c|c|}
\hline & 1990 & 1991 & 1992 & 1993 & 1994 & 1995 & 1996 & 1997 & 1998 & 1999 & 2000 & 2001 & 2002 & 2003 & 2004 \\
\hline OECD Countries & 20.11 & 19.99 & 19.82 & 19.63 & 20.26 & 19.75 & 20.25 & 20.35 & 20.03 & 20.66 & 20.84 & 20.96 & 20.66 & 20.81 & 20.54 \\
\hline African Countries & 16.17 & 15.54 & 15.67 & 16.41 & 16.52 & 17.78 & 17.32 & 17.33 & 16.91 & 17.47 & 17.77 & 17.36 & 17.82 & 20.62 & 22.83 \\
\hline Asian and Pacific Countries & 14.08 & 13.18 & 13.05 & 13.21 & 13.58 & 14.19 & 14.37 & 13.89 & 12.85 & 13.76 & 13.78 & 14.93 & 14.28 & 15.34 & 16.52 \\
\hline European Countries 2/ & 21.40 & 20.94 & 20.73 & 20.72 & 20.81 & 19.83 & 20.36 & 20.78 & 20.18 & 20.57 & 20.66 & 19.83 & 19.47 & 20.16 & 19.88 \\
\hline Middle East and Central Asian Countries & 12.75 & 12.89 & 13.53 & 13.55 & 15.29 & 14.88 & 13.62 & 13.32 & 12.52 & 12.46 & 15.88 & 14.62 & 14.19 & 11.65 & 13.34 \\
\hline Western Hemisphere Countries & 12.60 & 14.00 & 14.81 & 15.96 & 15.78 & 14.94 & 14.08 & 14.53 & 14.07 & 14.17 & 15.76 & 15.87 & 16.05 & 17.09 & 17.67 \\
\hline Unweighted average 3 / & 16.19 & 16.09 & 16.27 & 16.58 & 17.04 & 16.89 & 16.67 & 16.70 & 16.09 & 16.51 & 17.45 & 17.26 & 17.08 & 17.61 & 18.46 \\
\hline
\end{tabular}

Sources: Government Finance Statistics (IMF); International Financial Statistics (IMF); and World Economic Outlook (IMF).

1/ When the data are not reported as Consolidated Central Government we used General or Budgetary Central Governemnt.

2/ Including OECD countries.

3/ For each revenue classification, only countries for which data are available are included in the calculation.

${ }^{11}$ From IMF's Fiscal Affairs Department revenue database. 
Table 3. Consolidated Central Government: Taxes on Income, Profits, and Capital Gains by Region, 1990-2004 1/

(In percent of GDP)

\begin{tabular}{|c|c|c|c|c|c|c|c|c|c|c|c|c|c|c|c|}
\hline & 1990 & 1991 & 1992 & 1993 & 1994 & 1995 & 1996 & 1997 & 1998 & 1999 & 2000 & 2001 & 2002 & 2003 & 2004 \\
\hline OECD Countries & 9.26 & 9.31 & 8.97 & 8.84 & 8.95 & 8.81 & 9.09 & 9.21 & 9.10 & 9.19 & 9.69 & 10.04 & 9.74 & 9.91 & 10.10 \\
\hline African Countries & 5.27 & 4.82 & 5.12 & 5.12 & 4.98 & 5.15 & 5.59 & 5.55 & 5.26 & 5.38 & 5.14 & 5.05 & 5.39 & 5.89 & 5.23 \\
\hline Asian and Pacific Countries & 4.48 & 4.68 & 4.68 & 4.98 & 4.59 & 4.49 & 4.70 & 4.65 & 4.43 & 4.96 & 5.13 & 6.37 & 6.07 & 6.51 & 6.63 \\
\hline European Countries 2/ & 9.02 & 9.03 & 8.20 & 7.94 & 7.98 & 7.43 & 7.65 & 7.83 & 7.29 & 7.41 & 7.73 & 7.45 & 7.13 & 7.07 & 6.89 \\
\hline Middle East and Central Asian Countries & 4.16 & 4.23 & 3.94 & 3.99 & 5.09 & 5.16 & 5.16 & 4.93 & 4.22 & 4.42 & 6.74 & 5.94 & 5.53 & 2.77 & 3.28 \\
\hline Western Hemisphere Countries & 4.13 & 4.47 & 4.84 & 5.27 & 5.05 & 4.48 & 4.04 & 4.30 & 4.02 & 4.05 & 5.60 & 5.32 & 5.04 & 5.22 & 5.59 \\
\hline Unweighted average 3 / & 6.05 & 6.09 & 5.96 & 6.03 & 6.11 & 5.92 & 6.04 & 6.08 & 5.72 & 5.90 & 6.67 & 6.70 & 6.48 & 6.23 & 6.28 \\
\hline
\end{tabular}

Sources: Government Finance Statistics (IMF); International Financial Statistics (IMF); and World Economic Outlook (IMF).

1/ When the data are not reported as Consolidated Central Government we used General or Budgetary Central Governemnt.

2/ Including OECD countries.

3/ For each revenue classification, only countries for which data are available are included in the calculation.

Table 4. Consolidated Central Government: Taxes on Individuals by Region, 1990-2004 1/

(In percent of GDP)

\begin{tabular}{|c|c|c|c|c|c|c|c|c|c|c|c|c|c|c|c|}
\hline & 1990 & 1991 & 1992 & 1993 & 1994 & 1995 & 1996 & 1997 & 1998 & 1999 & 2000 & 2001 & 2002 & 2003 & 2004 \\
\hline OECD Countries & 6.75 & 6.89 & 6.80 & 6.40 & 6.45 & 6.34 & 6.37 & 6.29 & 6.49 & 6.29 & 6.35 & 6.85 & 6.76 & 6.86 & 6.78 \\
\hline African Countries & 1.77 & 1.62 & 1.74 & 1.77 & 1.66 & 2.21 & 2.80 & 2.84 & 2.41 & 2.95 & 2.68 & 2.60 & 2.38 & 2.82 & 0.85 \\
\hline Asian and Pacific Countries & 1.65 & 1.71 & 1.57 & 1.44 & 1.36 & 1.44 & 1.59 & 1.61 & 1.63 & 1.94 & 1.93 & 2.36 & 2.60 & 2.89 & 3.25 \\
\hline European Countries 2/ & 6.01 & 5.99 & 5.92 & 5.48 & 5.39 & 5.02 & 5.14 & 5.08 & 4.86 & 4.83 & 4.84 & 4.72 & 4.67 & 4.47 & 4.16 \\
\hline Middle East and Central Asian Countries & 0.76 & 0.82 & 0.81 & 0.97 & 0.93 & 0.93 & 0.69 & 0.93 & 1.42 & 1.53 & 1.01 & 1.10 & 1.05 & 1.02 & 1.18 \\
\hline Western Hemisphere Countries & 0.46 & 0.57 & 0.82 & 1.14 & 1.04 & 1.23 & 0.95 & 0.96 & 0.91 & 0.93 & 2.24 & 2.30 & 2.24 & 2.05 & 2.39 \\
\hline Unweighted average 3 / & 2.90 & 2.93 & 2.94 & 2.86 & 2.80 & 2.86 & 2.92 & 2.95 & 2.95 & 3.08 & 3.18 & 3.32 & 3.28 & 3.35 & 3.10 \\
\hline
\end{tabular}

Sources: Government Finance Statistics (IMF); International Financial Statistics (IMF); and World Economic Outlook (IMF).

1/ When the data are not reported as Consolidated Central Government we used General or Budgetary Central Governemnt.

2/ Including OECD countries.

3/ For each revenue classification, only countries for which data are available are included in the calculation.

Table 5. Consolidated Central Government: Corporations and Other Enterprises Taxes by Region, 1990-2004 1/

(In percent of GDP)

\begin{tabular}{|c|c|c|c|c|c|c|c|c|c|c|c|c|c|c|c|}
\hline & 1990 & 1991 & 1992 & 1993 & 1994 & 1995 & 1996 & 1997 & 1998 & 1999 & 2000 & 2001 & 2002 & 2003 & 2004 \\
\hline OECD Countries & 2.26 & 2.05 & 1.79 & 2.01 & 2.10 & 2.19 & 2.39 & 2.56 & 2.36 & 2.56 & 2.81 & 2.89 & 2.83 & 2.92 & 3.16 \\
\hline African Countries & 3.06 & 2.55 & 2.49 & 2.48 & 1.95 & 1.96 & 1.95 & 1.68 & 1.54 & 1.54 & 1.39 & 2.00 & 2.51 & 2.78 & 4.04 \\
\hline Asian and Pacific Countries & 2.24 & 2.31 & 2.43 & 2.89 & 2.67 & 2.37 & 2.62 & 2.58 & 2.26 & 2.52 & 2.63 & 2.86 & 2.92 & 3.13 & 2.79 \\
\hline European Countries 2/ & 2.81 & 2.79 & 2.09 & 2.26 & 2.40 & 2.25 & 2.33 & 2.57 & 2.30 & 2.44 & 2.57 & 2.46 & 2.33 & 2.46 & 2.57 \\
\hline Middle East and Central Asian Countries & 2.67 & 2.60 & 2.36 & 2.42 & 2.40 & 2.23 & 2.28 & 2.14 & 1.72 & 1.51 & 2.37 & 2.37 & 1.92 & 1.57 & 1.88 \\
\hline Western Hemisphere Countries & 2.46 & 2.61 & 2.66 & 2.73 & 2.70 & 1.94 & 1.84 & 1.97 & 1.66 & 1.80 & 1.98 & 1.95 & 1.89 & 2.24 & 2.26 \\
\hline Unweighted average 3 / & 2.58 & 2.49 & 2.30 & 2.46 & 2.37 & 2.16 & 2.23 & 2.25 & 1.97 & 2.06 & 2.29 & 2.42 & 2.40 & 2.52 & 2.78 \\
\hline
\end{tabular}

Sources: Government Finance Statistics (IMF); International Financial Statistics (IMF); and World Economic Outlook (IMF).

1/ When the data are not reported as Consolidated Central Government we used General or Budgetary Central Governemnt.

2/ Including OECD countries.

3/ For each revenue classification, only countries for which data are available are included in the calculation. 
Table 6. Consolidated Central Government: Taxes on Payroll and Workforce by Region, 1990-2004 1/

(In percent of GDP

\begin{tabular}{|c|c|c|c|c|c|c|c|c|c|c|c|c|c|c|c|}
\hline & 1990 & 1991 & 1992 & 1993 & 1994 & 1995 & 1996 & 1997 & 1998 & 1999 & 2000 & 2001 & 2002 & 2003 & 2004 \\
\hline OECD Countries & 0.26 & 0.23 & 0.21 & 0.18 & 0.15 & 0.17 & 0.16 & 0.19 & 0.26 & 0.30 & 0.21 & 0.23 & 0.25 & 0.28 & 0.17 \\
\hline African Countries & 0.07 & 0.01 & 0.01 & 0.01 & 0.03 & 0.03 & 0.04 & 0.03 & 0.03 & 0.04 & 0.04 & 0.15 & 0.16 & 0.24 & 0.20 \\
\hline Asian and Pacific Countries & 0.00 & 0.00 & 0.00 & 0.00 & 0.00 & 0.00 & 0.00 & 0.00 & 0.01 & 0.11 & 0.12 & 0.12 & 0.12 & 0.14 & 0.18 \\
\hline European Countries 2/ & 0.53 & 0.28 & 0.37 & 0.33 & 0.26 & 0.27 & 0.27 & 0.30 & 0.28 & 0.33 & 0.28 & 0.29 & 0.29 & 0.41 & 0.37 \\
\hline Middle East and Central Asian Countries & 0.15 & 0.13 & 0.15 & 0.15 & 0.13 & 0.15 & 0.18 & 0.15 & 0.17 & 0.16 & 0.66 & 0.60 & 0.57 & 0.44 & 0.42 \\
\hline Western Hemisphere Countries & 0.11 & 0.09 & 0.10 & 0.09 & 0.07 & 0.06 & 0.08 & 0.14 & 0.12 & 0.00 & 0.06 & 0.14 & 0.16 & 0.28 & 0.14 \\
\hline Unweighted average 3 / & 0.18 & 0.12 & 0.14 & 0.13 & 0.11 & 0.11 & 0.12 & 0.14 & 0.15 & 0.16 & 0.23 & 0.25 & 0.26 & 0.30 & 0.24 \\
\hline
\end{tabular}

Sources: Government Finance Statistics (IMF); International Financial Statistics (IMF); and World Economic Outlook (IMF).

1/ When the data are not reported as Consolidated Central Government we used General or Budgetary Central Governemnt.

2/ Including OECD countries.

3/ For each revenue classification, only countries for which data are available are included in the calculation.

Table 7. Consolidated Central Government: Property Taxes by Region, 1990-2004 1/

(In percent of GDP)

\begin{tabular}{|c|c|c|c|c|c|c|c|c|c|c|c|c|c|c|c|}
\hline & 1990 & 1991 & 1992 & 1993 & 1994 & 1995 & 1996 & 1997 & 1998 & 1999 & 2000 & 2001 & 2002 & 2003 & 2004 \\
\hline OECD Countries & 0.75 & 0.73 & 0.72 & 0.69 & 0.68 & 0.60 & 0.62 & 0.67 & 0.54 & 0.65 & 0.63 & 0.54 & 0.52 & 0.49 & 0.47 \\
\hline African Countries & 0.09 & 0.03 & 0.03 & 0.10 & 0.09 & 0.13 & 0.20 & 0.24 & 0.21 & 0.20 & 0.25 & 0.22 & 0.29 & 0.36 & 0.09 \\
\hline Asian and Pacific Countries & 0.28 & 0.30 & 0.28 & 0.26 & 0.35 & 0.34 & 0.33 & 0.35 & 0.29 & 0.41 & 0.47 & 0.34 & 0.35 & 0.46 & 0.48 \\
\hline European Countries 2/ & 0.79 & 0.73 & 0.64 & 0.61 & 0.58 & 0.53 & 0.53 & 0.55 & 0.45 & 0.52 & 0.52 & 0.44 & 0.45 & 0.38 & 0.37 \\
\hline Middle East and Central Asian Countries & 0.29 & 0.34 & 0.35 & 0.38 & 0.31 & 0.28 & 0.20 & 0.33 & 0.30 & 0.30 & 0.42 & 0.42 & 0.46 & 0.45 & 0.52 \\
\hline Western Hemisphere Countries & 0.32 & 0.30 & 0.28 & 0.25 & 0.30 & 0.21 & 0.19 & 0.17 & 0.18 & 0.41 & 0.72 & 0.82 & 0.97 & 1.06 & 1.19 \\
\hline Unweighted average 3 / & 0.42 & 0.41 & 0.38 & 0.38 & 0.39 & 0.35 & 0.34 & 0.38 & 0.33 & 0.42 & 0.50 & 0.46 & 0.51 & 0.53 & 0.52 \\
\hline
\end{tabular}

Sources: Government Finance Statistics (IMF); International Financial Statistics (IMF); and World Economic Outlook (IMF).

1/ When the data are not reported as Consolidated Central Government we used General or Budgetary Central Governemnt.

2/ Including OECD countries.

3/ For each revenue classification, only countries for which data are available are included in the calculation. 
Table 8. Consolidated Central Government: Taxes on Goods and Services by Region, 1990-2004 1/

(In percent of GDP)

\begin{tabular}{|c|c|c|c|c|c|c|c|c|c|c|c|c|c|c|c|}
\hline & 1990 & 1991 & 1992 & 1993 & 1994 & 1995 & 1996 & 1997 & 1998 & 1999 & 2000 & 2001 & 2002 & 2003 & 2004 \\
\hline OECD Countries & 9.19 & 9.17 & 9.34 & 9.33 & 9.85 & 9.58 & 9.85 & 9.82 & 9.61 & 10.05 & 9.94 & 9.74 & 9.84 & 9.79 & 9.59 \\
\hline African Countries & 4.62 & 4.52 & 4.71 & 4.78 & 4.58 & 4.96 & 5.01 & 5.21 & 5.65 & 5.50 & 5.24 & 5.06 & 5.57 & 6.46 & 9.17 \\
\hline Asian and Pacific Countries & 4.59 & 4.30 & 4.47 & 4.57 & 5.00 & 5.31 & 5.32 & 5.20 & 5.03 & 5.47 & 5.40 & 5.65 & 5.47 & 6.19 & 6.26 \\
\hline European Countries 2/ & 9.81 & 9.58 & 9.88 & 10.04 & 10.34 & 10.24 & 10.75 & 11.03 & 11.11 & 11.46 & 11.43 & 11.01 & 10.96 & 11.29 & 11.34 \\
\hline Middle East and Central Asian Countries & 3.91 & 3.91 & 4.38 & 4.59 & 4.76 & 4.90 & 4.06 & 4.49 & 4.47 & 4.58 & 5.29 & 5.05 & 4.89 & 5.78 & 6.29 \\
\hline Western Hemisphere Countries & 4.13 & 4.65 & 5.18 & 5.93 & 6.04 & 6.74 & 6.90 & 7.23 & 7.20 & 7.42 & 7.33 & 7.03 & 7.60 & 7.77 & 8.57 \\
\hline Unweighted average 3 / & 6.04 & 6.02 & 6.33 & 6.54 & 6.76 & 6.96 & 6.98 & 7.16 & 7.18 & 7.41 & 7.44 & 7.26 & 7.39 & 7.88 & 8.54 \\
\hline
\end{tabular}

Sources: Government Finance Statistics (IMF); International Financial Statistics (IMF); and World Economic Outlook (IMF).

1/ When the data are not reported as Consolidated Central Government we used General or Budgetary Central Governemnt.

2/ Including OECD countries.

3/ For each revenue classification, only countries for which data are available are included in the calculation.

Table 9. Consolidated Central Government: Taxes on Excises and Taxes on Specific Services by Region, 1990-2004 1/

(In percent of GDP)

\begin{tabular}{|c|c|c|c|c|c|c|c|c|c|c|c|c|c|c|c|}
\hline & 1990 & 1991 & 1992 & 1993 & 1994 & 1995 & 1996 & 1997 & 1998 & 1999 & 2000 & 2001 & 2002 & 2003 & 2004 \\
\hline OECD Countries & 2.86 & 3.00 & 3.15 & 3.14 & 3.36 & 3.29 & 3.38 & 3.25 & 3.16 & 3.29 & 3.11 & 3.00 & 3.11 & 3.17 & 3.03 \\
\hline African Countries & 1.37 & 1.43 & 1.61 & 1.39 & 1.22 & 1.41 & 1.44 & 1.61 & 1.74 & 1.50 & 0.96 & 1.12 & 1.24 & 0.92 & 1.72 \\
\hline Asian and Pacific Countries & 2.26 & 2.23 & 2.25 & 1.97 & 1.97 & 1.92 & 2.09 & 2.18 & 2.13 & 2.10 & 2.40 & 2.05 & 2.10 & 2.24 & 2.22 \\
\hline European Countries 2/ & 3.04 & 3.27 & 3.08 & 3.19 & 3.16 & 3.25 & 3.29 & 3.19 & 3.26 & 3.34 & 3.30 & 3.18 & 3.24 & 3.36 & 3.27 \\
\hline Middle East and Central Asian Countries & 1.55 & 1.58 & 1.80 & 1.81 & 2.10 & 1.95 & 1.65 & 1.76 & 1.75 & 1.55 & 1.28 & 1.18 & 1.16 & 1.14 & 1.02 \\
\hline Western Hemisphere Countries & 1.64 & 1.64 & 1.74 & 1.90 & 1.91 & 1.71 & 1.70 & 1.92 & 2.05 & 1.94 & 1.88 & 1.88 & 2.20 & 2.17 & 2.33 \\
\hline Unweighted average 3 / & 2.12 & 2.19 & 2.27 & 2.23 & 2.28 & 2.26 & 2.26 & 2.32 & 2.35 & 2.29 & 2.15 & 2.07 & 2.18 & 2.17 & 2.27 \\
\hline
\end{tabular}

Sources: Government Finance Statistics (IMF); International Financial Statistics (IMF); and World Economic Outlook (IMF).

1/ When the data are not reported as Consolidated Central Government we used General or Budgetary Central Governemnt.

2/ Including OECD countries.

3/ For each revenue classification, only countries for which data are available are included in the calculation. 
Table 10. Consolidated Central Government: International Trade Taxes and Transactions by Region, 1990-2004 1/ 2/

(In percent of GDP)

\begin{tabular}{|c|c|c|c|c|c|c|c|c|c|c|c|c|c|c|c|}
\hline & 1990 & 1991 & 1992 & 1993 & 1994 & 1995 & 1996 & 1997 & 1998 & 1999 & 2000 & 2001 & 2002 & 2003 & 2004 \\
\hline OECD Countries $3 / 4$ / & 0.60 & 0.49 & 0.50 & 0.47 & 0.53 & 0.49 & 0.46 & 0.37 & 0.33 & 0.31 & 0.29 & 0.26 & 0.21 & 0.21 & 0.18 \\
\hline African Countries & 5.89 & 5.94 & 5.60 & 6.23 & 6.66 & 7.37 & 6.15 & 5.90 & 5.59 & 6.07 & 6.75 & 6.67 & 6.29 & 7.41 & 7.71 \\
\hline Asian and Pacific Countries & 4.40 & 3.49 & 3.25 & 3.01 & 3.11 & 3.61 & 3.57 & 3.18 & 2.69 & 2.51 & 2.33 & 2.16 & 2.05 & 1.89 & 2.82 \\
\hline European Countries 4/ & 1.10 & 1.02 & 1.31 & 1.44 & 1.35 & 1.09 & 0.88 & 0.80 & 0.75 & 0.63 & 0.58 & 0.54 & 0.52 & 0.80 & 0.75 \\
\hline Middle East and Central Asian Countries & 3.70 & 3.70 & 4.07 & 3.73 & 4.30 & 3.78 & 3.39 & 2.91 & 2.97 & 2.59 & 2.33 & 2.16 & 2.16 & 1.60 & 1.80 \\
\hline Western Hemisphere Countries & 3.56 & 4.03 & 3.87 & 3.80 & 3.69 & 3.22 & 2.76 & 2.77 & 2.53 & 2.48 & 2.06 & 2.11 & 2.11 & 2.63 & 1.99 \\
\hline Unweighted average 5 / & 3.21 & 3.11 & 3.10 & 3.12 & 3.27 & 3.26 & 2.87 & 2.65 & 2.48 & 2.43 & 2.39 & 2.32 & 2.22 & 2.42 & 2.54 \\
\hline
\end{tabular}

Sources: Government Finance Statistics (IMF); International Financial Statistics (IMF); and World Economic Outlook (IMF).

1/ When the data are not reported as Consolidated Central Government we used General or Budgetary Central Governemnt.

2/ Includes profits of exports or import monopolies, exchange profits and taxes and other taxes on international trade and transactions.

3/ European Union countries do not report statistics on international trade taxes to Government Finance Statistics.

4/ Including OECD countries.

5/ For each revenue classification, only countries for which data are available are included in the calculation.

Table 11. Consolidated Central Government: Taxes on Customs and Other Import Duties by Region, 1990-2004 1/

(In percent of GDP)

\begin{tabular}{|c|c|c|c|c|c|c|c|c|c|c|c|c|c|c|c|}
\hline & 1990 & 1991 & 1992 & 1993 & 1994 & 1995 & 1996 & 1997 & 1998 & 1999 & 2000 & 2001 & 2002 & 2003 & 2004 \\
\hline OECD Countries & 0.59 & 0.48 & 0.49 & 0.47 & 0.52 & 0.51 & 0.48 & 0.38 & 0.34 & 0.30 & 0.28 & 0.22 & 0.18 & 0.17 & 0.13 \\
\hline African Countries & 4.81 & 4.93 & 4.74 & 5.32 & 3.64 & 4.11 & 3.37 & 2.95 & 2.57 & 3.52 & 3.96 & 4.21 & 4.19 & 5.02 & 5.91 \\
\hline Asian and Pacific Countries & 4.06 & 3.23 & 3.02 & 2.76 & 2.86 & 3.40 & 3.35 & 2.78 & 2.55 & 2.49 & 2.19 & 1.91 & 1.78 & 1.76 & 2.72 \\
\hline European Countries $2 /$ & 1.06 & 1.03 & 1.17 & 1.23 & 1.18 & 1.04 & 0.88 & 0.84 & 0.73 & 0.52 & 0.44 & 0.40 & 0.38 & 0.68 & 0.51 \\
\hline Middle East and Central Asian Countries & 3.27 & 3.26 & 3.61 & 3.59 & 3.35 & 3.27 & 3.13 & 2.76 & 2.82 & 2.43 & 2.22 & 2.06 & 1.85 & 1.30 & 1.57 \\
\hline Western Hemisphere Countries & 2.99 & 3.54 & 3.46 & 3.38 & 3.44 & 3.02 & 2.54 & 2.58 & 2.35 & 2.33 & 1.95 & 2.01 & 1.93 & 2.49 & 1.81 \\
\hline Unweighted average 3 / & 2.80 & 2.74 & 2.75 & 2.79 & 2.50 & 2.56 & 2.29 & 2.05 & 1.89 & 1.93 & 1.84 & 1.80 & 1.72 & 1.90 & 2.11 \\
\hline
\end{tabular}

Sources: Government Finance Statistics (IMF); International Financial Statistics (IMF); and World Economic Outlook (IMF).

1/ When the data are not reported as Consolidated Central Government we used General or Budgetary Central Governemnt.

2/ Including OECD countries.

3/ For each revenue classification, only countries for which data are available are included in the calculation 
Table 12. Consolidated Central Government: Taxes on Exports by Region, 1990-2004 1/

(In percent of GDP)

\begin{tabular}{|c|c|c|c|c|c|c|c|c|c|c|c|c|c|c|c|}
\hline & 1990 & 1991 & 1992 & 1993 & 1994 & 1995 & 1996 & 1997 & 1998 & 1999 & 2000 & 2001 & 2002 & 2003 & 2004 \\
\hline OECD Countries & 0.02 & 0.00 & 0.00 & 0.00 & 0.00 & 0.00 & 0.00 & 0.00 & 0.00 & 0.00 & 0.00 & 0.00 & 0.00 & 0.00 & 0.00 \\
\hline African Countries & 0.68 & 0.59 & 0.45 & 0.15 & 0.49 & 0.54 & 0.36 & 0.27 & 0.34 & 0.24 & 0.28 & 0.29 & 0.29 & 0.43 & 0.41 \\
\hline Asian and Pacific Countries & 0.30 & 0.20 & 0.18 & 0.20 & 0.24 & 0.21 & 0.22 & 0.40 & 0.11 & 0.11 & 0.24 & 0.10 & 0.03 & 0.05 & 0.03 \\
\hline European Countries 2/ & 0.02 & 0.02 & 0.04 & 0.15 & 0.03 & 0.05 & 0.02 & 0.00 & 0.00 & 0.02 & 0.07 & 0.08 & 0.07 & 0.11 & 0.20 \\
\hline Middle East and Central Asian Countries & 0.04 & 0.05 & 0.04 & 0.05 & 0.04 & 0.27 & 0.13 & 0.06 & 0.04 & 0.02 & 0.01 & 0.01 & 0.01 & 0.13 & 0.02 \\
\hline Western Hemisphere Countries & 0.14 & 0.10 & 0.08 & 0.04 & 0.03 & 0.03 & 0.02 & 0.01 & 0.01 & 0.00 & 0.00 & 0.00 & 0.09 & 0.13 & 0.15 \\
\hline Unweighted average 3 / & 0.20 & 0.16 & 0.13 & 0.10 & 0.14 & 0.18 & 0.12 & 0.12 & 0.08 & 0.07 & 0.10 & 0.08 & 0.08 & 0.14 & 0.14 \\
\hline
\end{tabular}

Sources: Government Finance Statistics (IMF); International Financial Statistics (IMF); and World Economic Outlook (IMF).

1/ When the data are not reported as Consolidated Central Government we used General or Budgetary Central Governemnt.

2/ Including OECD countries.

3/ For each revenue classification, only countries for which data are available are included in the calculation.

Table 13. Consolidated Central Government: Taxes on Social Contributions by Region, 1990-2004 1/

\begin{tabular}{|c|c|c|c|c|c|c|c|c|c|c|c|c|c|c|c|}
\hline & 1990 & 1991 & 1992 & 1993 & 1994 & 1995 & 1996 & 1997 & 1998 & 1999 & 2000 & 2001 & 2002 & 2003 & 2004 \\
\hline OECD Countries & 7.50 & 7.77 & 8.09 & 8.33 & 8.45 & 8.47 & 8.72 & 8.82 & 9.14 & 9.74 & 9.91 & 10.12 & 10.38 & 10.99 & 10.18 \\
\hline African Countries & 0.28 & 0.24 & 0.18 & 0.19 & 0.21 & 0.23 & 0.25 & 0.26 & 0.21 & 0.19 & 0.24 & 0.26 & 0.77 & 1.03 & 2.16 \\
\hline Asian and Pacific Countries & 0.09 & 0.10 & 0.23 & 0.21 & 0.24 & 0.33 & 0.32 & 0.37 & 0.45 & 0.40 & 0.55 & 1.00 & 0.88 & 1.05 & 0.12 \\
\hline European Countries 2/ & 8.60 & 8.58 & 9.50 & 9.59 & 9.39 & 8.95 & 9.53 & 9.57 & 10.02 & 10.76 & 11.07 & 10.94 & 11.22 & 11.97 & 11.66 \\
\hline Middle East and Central Asian Countries & 1.17 & 1.14 & 1.00 & 1.07 & 0.98 & 1.03 & 0.93 & 0.82 & 0.99 & 1.12 & 0.89 & 1.19 & 1.17 & 1.52 & 1.79 \\
\hline Western Hemisphere Countries & 2.17 & 2.07 & 2.08 & 2.23 & 2.18 & 1.71 & 1.75 & 2.26 & 2.40 & 1.91 & 2.57 & 2.66 & 2.79 & 3.16 & 3.44 \\
\hline Unweighted average 3 / & 3.30 & 3.32 & 3.51 & 3.60 & 3.58 & 3.45 & 3.58 & 3.68 & 3.87 & 4.02 & 4.21 & 4.36 & 4.54 & 4.95 & 4.89 \\
\hline
\end{tabular}

Sources: Government Finance Statistics (IMF); International Financial Statistics (IMF); and World Economic Outlook (IMF).

1/ When the data are not reported as Consolidated Central Government we used General or Budgetary Central Governemnt.

2/ Including OECD countries.

3/ For each revenue classification, only countries for which data are available are included in the calculation. 


\section{Appendix II: Data Sources}

Taxes: IMF Fiscal Affairs Department Tax Revenue Database, http://wwwint.imf.org/depts/fad/info_guide/info_resources/databases/taxrevenue.htm

Real income per capita: International Financial Statistics.

Nonhydrocarbon GDP: IMF country desks.

Share of agriculture in economy: World Development Indicators.

Openness: Calculated ratio to GDP of the sum of exports and imports; World Development Indicators.

Inflation: CPI data, International Financial Statistics.

Corruption: International Country Risk Guide (ICRG) Corruption Index, http://www.icrgonline.com/ 


\section{REFERENCES}

Abed, George T., and Gupta, Sanjeev, eds., 2002, Governance, Corruption, and Economic Performance (Washington, DC: International Monetary Fund).

Afonso, A., L. Schuknecht, and V. Tanzi, 2005, "Public Sector Efficiency: An International Comparison,” Public Choice, Vol. 123, No. 3-4, pp. 321-47.

Baer, Katherine, Olivier Benon, and Juan Toro, 2002, "Improving Large Taxpayers' Compliance: A Review of Country Experience," IMF Occasional Paper No. 215 (Washington, DC: International Monetary Fund).

Bond, Steven, Anke Hoeffler and Jonathan Temple, 2001, "GMM Estimation of Empirical Growth Models," CEPR Discussion Paper No. 3048

Blundell, Richard, and Steven Bond, 1998, "Initial Conditions and Moment Restrictions in Dynamic Panel Data Models," Journal of Econometrics, Vol. 87, pp.115-43.

Crandall, William, and Jean-Paul Bodin, 2005, "Revenue Administration Reform in Middle Eastern Countries, 1994-2004," Working Paper No. 203 (Washington, DC: International Monetary Fund).

Dos Santos, P.S., 1995, "Corruption in Tax Administration," presented at the Twenty-Ninth Annual Assembly of the Inter-American Center of Tax Administrators (CIAT), Lima, Peru, March 29, 1995.

Ebrill, Liam, Michael Keen, Jean-Paul Bodin, and Victoria Summers, 2001, The Modern VAT (Washington, DC: International Monetary Fund)

Ernst and Young, 2003, "Corporate Taxation in the Middle East." Available via the Internet: http://www.ey.com/global/download.nsf/Middle_East/Corporate_Taxation_Booklet/\$file/Cor porate $\% 20$ Taxation $\% 20$ booklet.pdf .

Friedman, Eric, Simon Johnson, Daniel Kaufmann and Pablo Zoido-Lobaton (2000) "Dodging the Grabbing Hand: The Determinants of Unofficial Activity in 69 Countries" Journal of Public Economics, Vol. 76, pp. 459-493

Gray, Cheryl, Joel Hellman, and Randi Ryterman, 2004, Anticorruption in Transition 2, Corruption in Enterprise-State Interactions in Europe and Central Asia 1999-2002 (Washington, DC: World Bank).

Ivanova, Anna, Keen, Michael, and Klemm, Alexander, 2005, "The Russian Flat Tax Reform," Working Paper No. 16 (Washington, DC: International Monetary Fund).

Katulis, Brian, 2004, Countries at the Crossroads (Washington, DC: Freedom House). 
Keen, Michael, 2003, Changing Customs: Challenges and Strategies for the Reform of Customs Administrations (Washington, DC: International Monetary Fund).

and Alejandro Simone, 2004, "Tax Policy in Developing Countries: Some Lessons from the 1990s and Some Challenges Ahead," in Helping Countries Develop: The Role of Fiscal Policy, ed. by Sanjeev Gupta, Benedict Clements, and Gabriele Inchauste (Washington, DC: International Monetary Fund).

OECD, 2005, Consumption Tax Trends: VAT/GST and Excise Rates, Trends and Administrative Issues, 2004 Edition (Paris: Organization for Economic Cooperation and Development).

OPEC, 2004, Annual Statistical Bulletin (Vienna: Organization of Petrol Exporting Countries).

Rodriguez, Francesco, and Dani Rodrik, 1999, "Trade Policy and Economic Growth: A Skeptic's Guide to Cross-National Evidence,” NBER Working Paper No. 7081 (Cambridge: Massachusetts: National Bureau of Economic Research)

Shleifer, Andrei, and Robert W. Vishny, 1993, “Corruption,” Quarterly Journal of Economics, Vol. 108, pp. 559-617.

Tanzi, Vito, 1998, "Corruption Around the World: Causes, Consequences, Scope, and Cures," Working Paper No. 63 (Washington, DC: International Monetary Fund). , and Howell Zee, 2000, "Tax Policy for Margining Markets: Developing Countries," Working Paper No. 35 (Washington, DC: International Monetary Fund). , and Hamid R. Davoodi, 2002, "Corruption, Growth, and Public Finances," in Governance, Corruption, and Economic Performance, ed. by George T. Abed and Sanjeev Gupta (Washington, DC: International Monetary Fund).

Wei, Shang-Jin, 1997, "Why Is Corruption So Much More Taxing Than Tax? Arbitrariness Kills," NBER Working Paper No. W6255 (Cambridge: Massachusetts: National Bureau of Economic Research) 